\title{
GAUSS SZÛRŐ ALKALMAZHATÓSÁGA ABRÁZIÓSAN KOPTATOTT FELÜLETEK MIKROTOPOGRÁFIÁJÁNAK VIZSGÁLATAKOR
}

\section{THE EXAMINATION OF APPLICATIBILITY OF GAUSSIAN MICROTOPOGRAPHY FILTER IN A CASE OF ABRASION WEAR PROCESS}

\author{
Barányi István \\ Óbudai Egyetem, Bánki Donát Gépész és Biztonságtechnikai Mérnöki Kar, 1081, \\ Magyarország, Budapest, Népszínház u. 8.; Telefon / Fax: +36-1-666-5314, \\ baranyi.istvan@bgk.uni-obuda.hu
}

\begin{abstract}
The microtopography measurement standards have evolved significantly in recent years. An increasing number of regulations and recommendations can be found in the currently used standards. In contrast, the current tribological literature and the standards aren't consist - evidence measurements - any prescription or recommendation to the filtering technology which separate the shape, roughness and waviness.

In the present article the author use Gaussian filtering method (with different nesting index) in a case of abraded microtopography and examines how to use different nesting index in tribology research.

Keywords: Nesting index, abrasion, wear

\section{Összefoglalás}

A mikrotopográfiai mérések szabványai jelentősen fejlődésen mentek keresztül az utóbbi években. Egyre több előírás és ajánlás található a jelenleg hatályban lévő szabványokban. Ezzel szemben jelenleg a tribológiai szakirodalmakban és a vonatkozó szabványokban sem található konkrét mérésekkel bizonyított - előírás vagy ajánlás arra vonatkozóan, hogy az alakhiba, hullámosság és érdesség milyen szürési beállításokkal kerüljön szétválasztásra.

Jelen cikkben a szerző egy abráziós körülmények között koptatott mikrotopográfián végez Gauss szürő segítségével jelanalízist és azt vizsgálja, hogy a szabványok által elöírt vágási hullámhosszak miként használhatók tribológiai kutatásokban.
\end{abstract}

Kulcsszavak: vágási hullámhossz, abrázió, kopás

\section{Bevezetés}

Az profilometria esetében alkalmazott érdességmérési szabványokról elmondható, hogy a kutatói életben és az ipari gyakorlatban is megfelelően alkalmazhatóak, alapkoncepciókban az utóbbi évtizedekben változás nem történt. A hatályban lévő ISO 4288-as szabvány szüréstechnikai szempontból két részre osztja a gyártott felületeket: periódikus profil esetén az RSm érték, nem periódikus profil esetén az $\mathrm{Ra}, \mathrm{Rz}$ értéke mondja meg az érdességet és a hullámosságot szétválasztó hullámhosszt.

A jelenleg folyamatosan új fezetekkel bővülö ISO 16610-es (a mikrotopográfiai mérésekkel is foglalkozó) szabvány a szürési megoldásoknál három dimenzióba 
terjeszti ki a szürők karakterisztikáját. Az így megvalósított szürési lehetőségekre a szabvány kopott felületek esetében nem tesz ajánlást.

A szakirodalmat tekintve Marko és szerzőtársai [1] cikkükben a ferdeségi és a lapultsági mérőszámokat szüréssel határozták meg és hozták kapcsolatba a tribológiai viselkedéssel.

Wang és szerzőtársai [2] szüretlen paraméterekkel generált felületek esetén vizsgálják a határkenési állapotot topográfiai paraméterekkel és a valós érintkezési zónát és a kontakt hőmérsékletet a FIR technikát alkalmazva.

Svahn [3] cikkében szürt vonalmenti érdességi paramétereket használ, de emellett szüretlen topográfiai képekkel is jellemzi a felületet.

Kopásdiagnosztikai szempontból elmondhatjuk, hogy a csúcszóna változások vizsgálata a mért jel feldolgozásától függ, azaz az alkalmazott szürő feltehetőleg különböző tribológiai tulajdonságokat tud jellemezni.

\section{Anyag és módszer}

\subsection{A domináns hullámhossz, valamint a hullámhossz összetevők vizsgálata}

A domináns hullámhossz összetevők meghatározására a szakirodalom több módszert is ajánl, melyek közül a gyakorlatban a Fourier transzformáció elterjedése figyelhető meg. A diszkrét pontokból álló profil Fourier transzformáltja meghatározható az (1) kifejezéssel:

$$
F\left(q_{p}\right)=\Delta x \sum_{i=1}^{M} z\left(x_{i}\right) e^{-j 2 \pi q_{p} x_{i}}
$$

$\mathrm{Az}$ így végrehajtott transzformáció eredménye két formában jeleníthető meg a hullámhossz függvényében: -lineáris léptékben, ahol kiugró lokális maximumként megjelennek a profilra jellemző domináns hullámhosszak,

- logaritmikus léptékben.

Mindkét megjelenítési stratégia más müszaki tartalmú kiértékelést tesz lehetővé. Lineáris léptékü hullámhossz ábrázoláskor egyrészről a domináns hullámhosszt, másrészről az egyes hullámhossz összetevők amplitúdóját tudjuk megkapni a (2) egyenlet segítségével.

$$
A\left(q_{p}\right)=\frac{F\left(q_{p}\right) F^{*}\left(q_{p}\right)}{M \Delta x}
$$

\subsection{A Gauss szűrő átviteli függvénye}

A Gauss szürő három dimenzióba történő kiterjesztése [4] szerint mindkét irányban különböző vágási hullámhosszokkal az (3) egyenlet alapján írható fel:

$$
S(x, y)=\frac{1}{\alpha \lambda_{c x} \alpha \lambda_{c y}} e^{-\pi\left(\frac{x}{\alpha \lambda_{c x}}\right)^{2}-\pi\left(\frac{y}{\alpha \lambda_{c y}}\right)^{2}}
$$

Ahol $\alpha$ állandó érték, melyet a (4) egyenlet definiál.

$$
\alpha=\sqrt{\frac{\ln 2}{\pi}}
$$

Az így meghatározott Gauss függvényt 2001 × 1997-es mátrix segítségével ábrázolva az 1. ábra szemlélteti egységnyi (1mmes) vágási hullámhossz esetén.

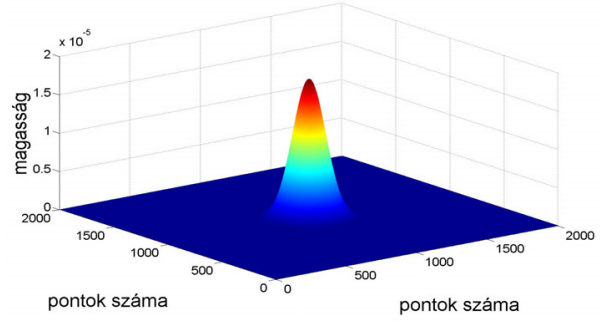

1. ábra. Az alkalmazott Gauss függvény egységnyi vágási hosszal minkét irányban 


\subsection{A vizsgált mikrotopográfia}

A vizsgálathoz alkalmazott mikrotopográfia elöállításakor $\mathrm{C} 45$ anyagon végeztem koptatási kísérleteket pin-on-plate elrendezésben. A koptatási úthossz $3000 \mathrm{~mm}$ volt, a felületeket összeszorító erő $300 \mathrm{~N}$. A vizsgálatkor 1200-as finomságú csiszolópapírt alkalmaztam, melynek segítségével száraz súrlódást valósítottam meg. Érdességméréskor $4 \mathrm{~mm} \times 4 \mathrm{~mm}$-es mikrotopográfiát mértem 2 mikronos lépésközzel. Az eredmény ponthalmazt $2001 \times 1997$-es mátrixban rögzítettem (2. ábra).

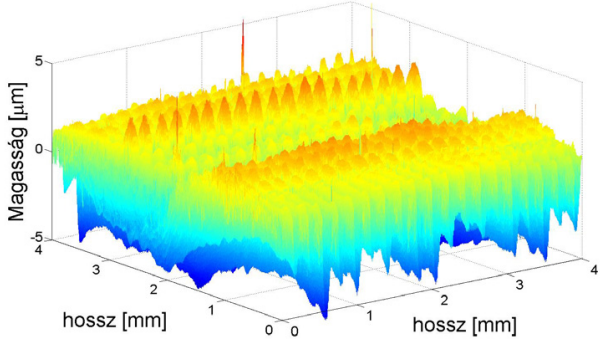

2. ábra. A kopott mikrotopográfia

A kiértékeléskor a szabvány által alkalmazott vágási hullámhosszakat vettem figyelembe mindkét irányban megegyező értékkel $(0,1 \mathrm{~mm} ; 0,2 \mathrm{~mm} ; 0,25 \mathrm{~mm} ; 0,5$ $\mathrm{mm} ; 0,8 \mathrm{~mm} ; 1 \mathrm{~mm} ; 2 \mathrm{~mm} ; 2,5 \mathrm{~mm}$ ).

\section{Eredmények}

A 2. ábra alapján elmondható, hogy a csúcszónákat az abráziós karcok, a völgyzónákat pedig a megmunkáló szerszám definiálták (a csúcszóna részlegesen semmisült meg). A csúcszóna és a völgyzóna egy-egy profilját és PSD analízisét a 3a. és a 3b. ábra szemlélteti 1024 mérési pontra vetítve.

A 3a-b. ábra szerint csúcs- és völgyzónát domináns hullámhossz alapján megkülön-böztetni nehézkes: mindkettő egy nagy értékü alakhibával rendelkezik, valamint a szabványos szürési hosszaknál közel azonos intenzitással vannak az egyes jelösszetevők.

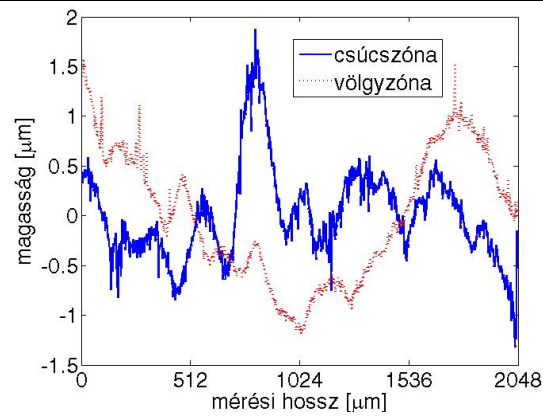

3a. ábra. A csúcs- és völgyzóna

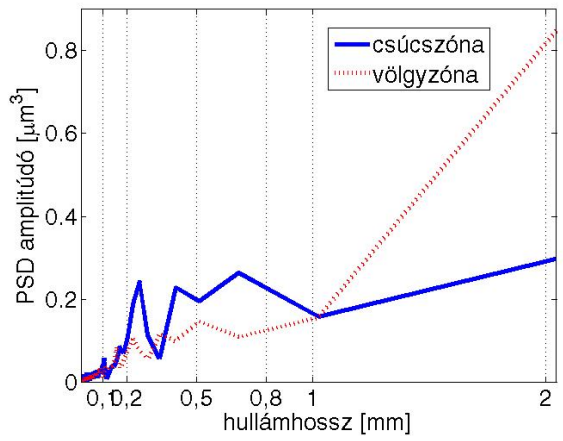

3b. ábra. A csúcs- és völgyzóna PSD analizise

A 4.-5. ábrák a vizsgált paraméterek és a vágási hullámhosszak kapcsolatát mutatják be. Az ábrákkal kapcsolatban elmondható, hogy a vágási hullámhossz növelésével a jeleknek egyre nagyobb része érdességi paraméterként jelenik meg, ezért az alkalmazott elötolás miatt a diagramok 0,2 mm-es hullámhossz értéknél jelentős mértékü változást mutatnak.

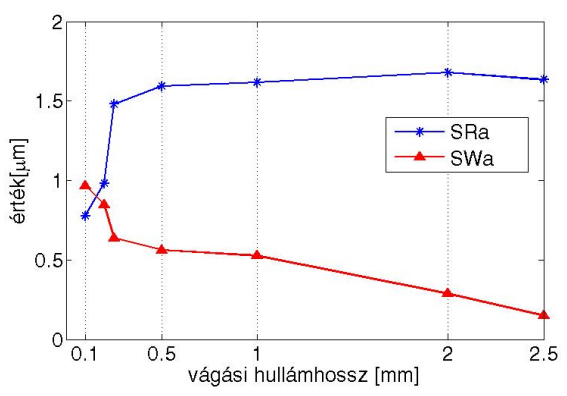

4. ábra. $A z \quad S a$ paraméter érdességi és hullámossági összetevöje 


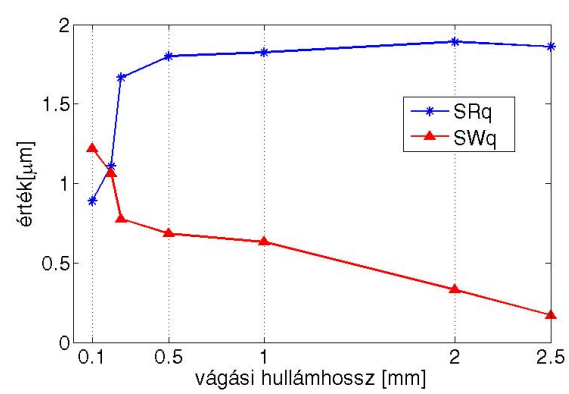

5. ábra. $A z \quad S q$ paraméter érdességi és hullámossági összetevője

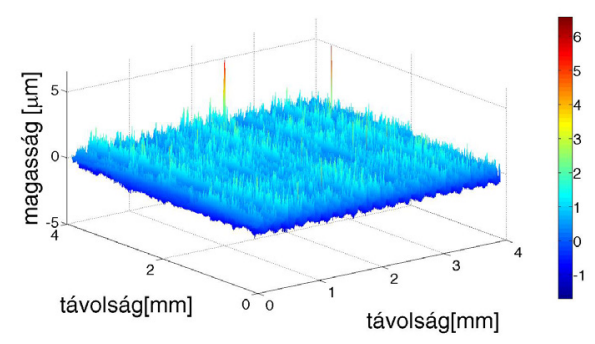

6. ábra. $A$ topográfia 0,1 mikron vágási hullámhossz esetén

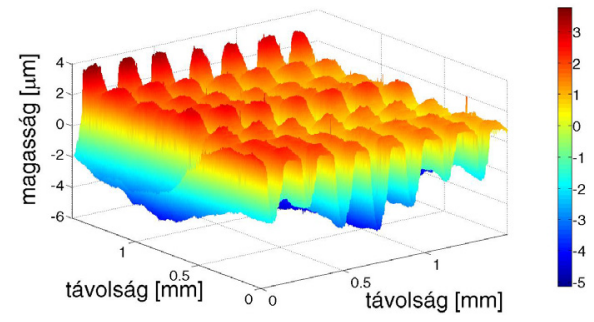

7. ábra. A topográfia 2,5 mikron vágási hullámhossz esetén

A 6. és 7. ábrák a legnagyobb és legkisebb vágási hullámhosszaknál kapott topográfiákat mutatják be

\section{Következtetések}

A vizsgált mikrotopográfia esetén elmondható, hogy nem sikerült a csúcszónában található karcokat hullámtérbe történő transzformációval azonosítani, valamint az alkalmazott szürések közül a 0,1 mm-es hullámhossz esetén is található a vizsgált esetben völgyzóna és csúcszóna jelösszetevő, valamint az előtoláshoz tartozó jel töredéke.

A több lépcsős szürési megoldások esetén alkalmazása esetén - a jeltartalom csökkenése miatt - a mérés elején már tudnunk kell a vizsgálandó jelek hullámhossz tartományát.

A csúcszóna jelösszetevők szürésére az eredmények alapján elmondható, hogy a teljes mérési adathalmazon alkalmazott konvolúciós megoldással szemben a lokális megoldások (csak a csúcszóna, mint adathalmaz vizsgálata), vagy a spline illetve FFT alapú szürési megoldások célravezetőbbek.

\section{Szakirodalmi hivatkozások}

[1] Marko Sedlcek, Bojan Podgornik, és mások: Correlation between standard roughness parameters skewness and kurtosis and tribological behaviour of contact surfaces. Tribology International (2012), Vol. 48, pp 102-112.

[2] Wang Wen-zhong, Chen Hui, és mások: Effect of surface roughness parameters on mixed lubrication characteristics. Tribology International (2006), Vol. 39, pp 522-527.

[3] Fredrik Svahn, Åsa Kassman-Rudolphi, és mások: The influence of surface roughness on friction and wear of machine element coatings, Wear (2003), vol 251, pp. 10921098

[4] Muralikrishnan, Balasubramanian, Raja, Jayaraman: Computational Surface and Roundness Metrology, Springer, 2009, pp. 33 